\title{
A review on tourist mall patronage determinant in Malaysia
}

\begin{abstract}
Nowadays, the economic benefits received from the fast growing tourism industry around the globe began to attract serious attention of many countries for the development of tourism sector. Shopping, as one of tourists' favored activities, has become a significant economic contributor to the tourism and retail industries. Therefore, it is inevitable to study the tourist's shopping behavior due to the unique context of tourism setting, which is often different on a day-to-day basis. Although, retail patronage have been extensively examined from a large number of determinants such as product relevant, market relevant and personal factors, there is scarcity in the body of knowledge examining shopping mall patronage which specifically addresses tourists shopping behavior in a developing country such as Malaysia. Hence, through developing a conceptual model, this study aims to expand our understanding of the nature of shopping mall patronage of tourist shopping behavior. More specifically this study aims to established the framework which provides new insights in explaining the relation of tourist shopping

behavior and mall patronage by adapting the theory of planned behavior (TPB) through a quantitative method of research.
\end{abstract}

Keywords: Mall patronage; Planned behaviour; Tourist; Theory of planned behaviour 